\title{
Merger Clauses in Contracts Governed By POLISH LAW
}

\author{
RADOSEAW STRUGAEA*
}

\section{INTRODUCTION}

A merger clause, also known as an entire agreement clause or integration clause, is a provision in a written contract stating that the contract represents the parties' complete and final agreement. Typically it uses the following wording: 'This Agreement represents the Parties' entire understanding regarding the subject matter herein' or 'The contract contains the entire contract and understanding between the parties hereto and supersedes all prior negotiations, representations, undertakings and agreements on any subject matter of the contract' ${ }^{1}$. This paper is concerned with merger clauses having the above or an equivalent formulation. More specific merger clauses, sometimes referred to as acknowledgements of nonreliance $^{2}$, remain outside the scope of the paper.

While originating from the common law system, merger clauses are commonly used within the context of international contracts ${ }^{3}$. Moreover, their insertion into purely domestic contracts governed by the civil law appears to be on the increase. As a result, merger clauses are to be found in both cross-border and domestic contracts, irrespective of whether they are subject to civil or to common law. This phenomenon pertains not only to merger clauses, but also to other contractual provisions from AngloAmerican jurisdictions. It is widely recognised that contract drafters all over

DOI: $10.2478 /$ wrlae-2013-0002

* PhD in Law, Assistant Professor, Department of Civil Law and International Private Law, Faculty of Law, Administration and Economics, University of Wroclaw; r.strugala@prawo.uni.wroc.pl

${ }^{1}$ See inter alia Marcel Fontaine and Filip de Ly, Drafting International Contracts (BRILL 2009) 130; Giuditta Cordero-Moss, 'Does the use of common law contract models give rise to a tacit choice of law or to a harmonised, transnational interpretation?' in Giuditta Cordero-Moss (ed), Boilerplate Clauses, International Commercial Contracts and the Applicable Law (Cambridge University Press 2011) 49; Henrik W. Bjørnstad, 'Entire agreement clauses' $<$ http://www.jus.uio.no/ifp/english/research/projects/anglo/essays/bjornstad abstract.pd f $>$ 1, accessed 20.02.2013; Giorgio De Nova, 'Il contratto. Dal contratto atipico al contratto alieno' (Cedam 2011) 34.

2 Bjørnstad (n 1) 2.

${ }^{3}$ Fontaine and de Ly (n 1) 129. 
Europe are generally inclined to use Anglo-American contract models ${ }^{4}$. A characteristic feature of the Anglo-American contract drafting model is the constant presence of so-called boilerplate clauses, of which the merger clause is an example. Boilerplate clauses are standardised contractual provisions appearing at the beginning or towards the end of contracts, usually under the heading of 'miscellaneous provisions'. Undoubtedly, one of the reasons for the spread of the Anglo-American contract model is the status of the English language in contemporary business relations. In a large percentage of cases, drafting contracts in English is not limited to the usage of the language itself, but also entails the application of contract models that have been developed in common law jurisdictions. This is mostly because separation of the use of the English language from the adoption of contractual structures used in English-speaking countries is very difficult. It would demand not only a deep knowledge of the common law system, but also a systematic juxtaposition between this legal system and the law governing the contract followed by revision of the contract, so that it becomes adequate for the governing law $^{6}$. Since an average contract drafter usually lacks such knowledge, many common law boilerplate clauses have spread in civil law countries more by custom than for the fulfilment of real needs. Very often they are simply copied from widely-available English language contract templates and samples. Apart from spontaneous spreading of boilerplate provisions there are, however, numerous instances of their purposive and sensible usage. In the case of merger clauses, the rationale behind their usage is that they help to minimise the risk of contracting by rendering the contract a self-sufficient source of the parties' obligations and rights. It is generally held that the use of merger clauses leads to the separation of the contract document from the precedent informal promises and agreements between the parties to a contract. Supposedly this is the effect that the parties intend to achieve by using merger clauses. Whether it is possible to reach this goal is, however, a completely different question. Not surprisingly, responses to it may differ significantly, depending on the law governing the contract. This paper examines the legal effects of merger clauses under Polish law. It does not cover the effects of merger clauses in

4 See The report concerning the research project 'Anglo-American Contract Models' organised through the Law Faculty's Department of Private Law, University of Oslo aimed at analysing the legal effects of contract models from common law systems when they are used in contracts governed by the civil law jurisdictions $<$ http://www.jus.uio.no/ifp/english/research/projects/anglo $>$ accessed 20.02.2013; See also Giuditta Cordero-Moss, 'Introduction' in Giuditta Cordero-Moss (ed), Boilerplate Clauses, International Commercial Contracts and the Applicable Law (Cambridge University Press 2011) 4-6.

5 Tina L Stark, 'Negotiating and drafting contract boilerplate' (ALM Publishing 2003) 9-10; Kenneth A Adams, 'A manual of style for contract drafting' (American Bar Association 2004) 60; L Berezowski, 'Jak czytać i rozumieć angielskie umowy? Praktyczny przewodnik’ (C.H. Beck 2008) 55-306; Lenné Eidson Espenschied, Contract drafting: powerful prose in transactional practice (American Bar Association 2010) 55-56; Bjørnstad (n 1) 2; Barbara Z Kielar, Katarzyna Michałowska, 'Umowa handlowa angielskie $\mathrm{i}$ polskie wzorce tekstowe' <http://www.translegis.com.pl/11 archiwum/LL 1 2.pdf>, accessed 20.022013.

${ }^{6}$ Giuditta Cordero-Moss (ed), 'Introduction to part 1' in Boilerplate Clauses, International Commercial Contracts and the Applicable Law (Cambridge University Press 2011) 9. 
the common law system. This subject has been discussed elsewhere from the perspective of a civil law specialist ${ }^{7}$.

It is worth stressing that the need for uniformity of private law at the European Union level has led to the design of model rules on merger clauses. One such rule is contained in Art. 72 of the Proposal for a Regulation of the European Parliament and of the Council on a Common European Sales Law (CESL), which follows the path of its predecessors: Art. 2-105 of the Principles of European Contract Law (PECL) and Art. II. 4-104 of the Draft Common Frame of Reference (DCFR). Although the CESL rule differs considerably from what was provided in PECL and DCFR, the idea of regulating the legal effects of merger clauses has always been present in the course of formulating model European private law rules. This is not the case in Poland, nor in many other Member States' domestic regimes. Nonetheless, it seems that as far as Polish law is concerned, the effects of merger clauses are not likely to be significantly different from those set out in the European private law model rules. Whether this is in fact the case cannot be established at this point, since the answer requires a detailed investigation on the effects of merger clauses in Polish law. More will be said in the conclusion of this paper. Before entering into an analysis of merger clauses under Polish law, some theoretical and methodological remarks are appropriate.

\section{METHODOLOGICAL AND THEORETICAL BACKGROUND}

Whatever the reason for their application, the fact is that Polish legal practitioners are often confronted with merger clauses in their day-to-day practice. Having encountered them in a contract, the lawyer needs to establish what function, if any, they have. In other words, he or she needs to determine the legal effects of the merger clause. Since the Polish Civil Code does not provide any regulation concerning merger clauses, their legal effects are to be ascertained in the light of general provisions on juridical acts. For this to be accomplished two theoretically separate stages of reasoning are required. First, interpretation of the merger clause that appeared in the contract. Second, assessment of the validity of such a clause. As emphasized above, the main purpose of the inclusion of merger clauses is to render the document the sole, self-sufficient source of the parties' rights and obligations. Read in this way, merger clauses are thought to exclude any additional sources which could complement the contract, be it their own statements and agreements preceding the moment of the signing or the contractual terms which may by implied pursuant to the statutory law ${ }^{8}$. Thus, in Polish law the interpretation of merger clauses suggests that they influence the process of interpreting contracts ${ }^{9}$, the process of determining

\footnotetext{
${ }^{7}$ Michał Romanowski, 'Skutki zastrzeżenia w umowie merger clause' (2011) 12 Przegląd Prawa Handlowego 6-7; Bjørnstad (n 1) 6-15.

8 See Radosław Strugała, Standardowe klauzule umowne: adaptacyjne, salwatoryjne, merger, interpretacyjne oraz pactum de forma (C.H. Beck 2013) $248-151$.

${ }^{9}$ Marcin Łolik, 'Charakter prawny klauzul integralności umowy w prawie polskim' (2007) 8 Przegląd Prawa Handlowego 54-58; Dorota Krekora-Zając, 'Klauzule integralności jako sposób regulacji stosunków między stronami i wykładni postanowień umowy' (2008) 2 Wojskowy Przegląd Prawniczy 78; Andrzej Szlęzak, 'Polemicznie o skutkach zastrzegania tzw. merger clause' (2013) 2 Przegląd Prawa Handlowego 31;
} 
their terms with respect to the parties' agreements prior to the signing of the contract document ${ }^{10}$ or so-called pre-contractual statements ${ }^{11}$, as well as the process of filling in gaps when the contract is deemed incomplete. These effects will be analysed further in this paper, in the order given above. However, it has been observed that the legal effects of merger clauses may appear different depending on whether the clauses were inserted into the contract itself (contract document) or into the standard terms of contract. Thus, analysing merger clauses in the standard terms of contract may require some additional assumptions, and therefore will not be covered in sections II to V of this paper. Analysis in those sections will only be undertaken with respect to merger clauses inserted into the contract document. Some remarks on merger clauses inserted into the standard terms of contract will be made in the conclusion of the paper (section VI).

Many problems that arise while dealing with the legal effects of merger clauses seem rooted in the ambiguity of some essential legal concepts, among which the notion of contract is of great importance. That is why insight into the very nature of the contract can help overcome at least some of the problems just mentioned. According to the traditional definition, held by most Polish civil law scholars ${ }^{12}$, the contract is a juridical act which consists of at least two declarations of will aimed at establishing, modifying or terminating a legal relationship. A legal relationship is understood as the rights and obligations enjoyed by subjects of civil law. Having said this, it may easily be observed that contracts and other juridical acts are thought to create rights or obligations. This leads Polish scholars to the conclusion that declarations of will express norms ${ }^{13}$. As such, they are commands addressed to an individual, by which defined conduct is imposed on him $^{14}$. It is important that declarations of will usually appear as indirect

Romanowski (n 7) 7-10.

${ }^{10}$ Romanowski (n 7) 11; Krekora-Zając (n 9) 78-80; Łolik (n 9) 53-58.

${ }^{11}$ Fryderyk Zoll, 'Uwagi do art. 92 Projektu - tzw. merger clause' (2010) 4 Transformacje Prawa Prywatnego 62.

12 Zbigniew Radwański, 'Teoria umów' (PWN 1977) 62; Piotr Machnikowski, Swoboda umów wedtug art. $353^{I}$ KC. Konstrukcja prawna (C.H. Beck 2005) 125; Witold Czachórski, Adam Brzozowski, Marek Safjan, Elżbieta Skowrońska-Bocian, Zobowiazania. Zarys wykładu (Lexis Nexis 2009) 118; Stefan Grzybowski, Prawo cywilne. Zarys części ogólnej (PWN 1974) 201; Mieczysław Piekarski in Zbigniew Resich, Jerzy Ignatowicz, Janusz Pietrzykowski, Józef Ignacy Bielski (eds) Kodeks cywilny. Komentarz, Tom 1 (Wydawnictwo Prawnicze 1972) 150; Michał Niedośpiał, 'Swoboda czynności prawnych' (STO 2004) 33; Michał Niedośpiał, 'Autonomia woli w części ogólnej prawa cywilnego’ (1984) 12 Państwo i Prawo 64.

13 Machnikowski (n 12) 129; Piotr Machnikowski in Edward Gniewek (ed), 'Kodeks cywilny. Komentarz' (C.H. Beck 2011) 147; Zbigniew Radwański, 'Zagadnienia ogólne czynności prawnych’ in Zbigniew Radwański (ed) System prawa prywatnego. Tom 2. Prawo cywilne - część ogólna, (C.H. Beck 2002) 18.

${ }^{14}$ Zygmunt Ziembiński, 'Kompetencja i norma kompetencyjna' (1969) 4 Ruch Prawniczy Ekonomiczny i Socjologiczny 23; Maciej Zieliński, 'Interpretacja jako proces dekodowania tekstu prawnego' (1972) 16; Maciej Zieliński, Zygmunt Ziembiński, Uzasadnianie twierdzeń, ocen i norm $w$ prawoznawstwie (PWN 1988) 57-59; Zygmunt Ziembiński, Maciej Zieliński, Dyrektywy i sposób ich wypowiadania (Biblioteka Myśli Semiotycznej 1992) 22-32; Zygmunt Ziembiński, Logika praktyczna (PWN 1999) 106110; Machnikowski (n 12) 24. 
commands ${ }^{15}$, i.e. those whose traditional grammatical classification is not an imperative ${ }^{16}$.

Undoubtedly, the meaning presented above constitutes the essence of the contract. However, the notion of contract is ambiguous. Depending on the context, it may also convey different meanings. For the purpose of further findings, it is vital to emphasize that the term 'contract' is often used to denote the document which embodies a contract in the sense of an agreement ${ }^{17}$. From this perspective, the term 'contract' is equivalent to 'text', that is all the expressions contained in it, as opposed to the strict meaning of the contract (contract in the agreement sense) which covers only those parts of the text that can be considered to express norms (declarations of will). Now it is clear that contract in the document sense is a broader concept, as is 'contractual clause' or 'contractual term' used in this context, for it does not necessarily mean an utterance of a prescriptive nature (an utterance which expresses norms). Having made this observation, we may draw a distinction between normative and non-normative contractual clauses, the latter being information about facts. For an expression contained in a contract (document) to be deemed normative (prescriptive), it is not only necessary that the parties intend to bring about the legal effects that it expresses, but it is also vital that the parties are empowered to do so. Whether they are or not is a question of the scope of freedom of contract. A contractual clause aimed at bringing about legal effects exceeding the scope of freedom of contract either tends to be void itself (partial invalidity) or leads to the invalidity of the whole contract (see Art. 58 (3) of the Polish Civil Code). It is crucial to note that in statutory law it is very probable that a non-normative clause has some legal meaning. It can be often treated as evidence of the facts relevant to a dispute concerning the contract that this clause is a part of. It follows from this that even if a contractual clause turns out to be ineffective, it may still serve as proof of some facts. Among these facts, some psychological states - for instance, the parties' intentions - may be of importance.

At the conclusion of these introductory remarks, it is worth mentioning that the word 'contract' is also used to indicate a legal relationship resulting from a contract in its primary sense ${ }^{18}$. This meaning will also be used later on in this paper, when by saying that a contract may be freely modified by the parties we will in fact mean the modification of the legal relationship. This will also be the case when pre-contractual clauses that become part of the contract are analysed.

15 See Maciej Zieliński, Interpretacja jako proces dekodowania tekstu prawnego (Wydawnictwo Naukowe Uniwersytetu im. Adama Mickiewicza w Poznaniu 1972) 46; Radwański, 'Zagadnienia ogólne czynności prawnych' (n 13) 18; Ziembiński, Zieliński (n 14) 69.

${ }^{16}$ Melvin Joseph Adler, A Pragmatic Logic for Commands (John Benjamins Publishing 1980) 2.

17 Karolina Włodarska-Dziurzyńska, Sankcje w prawie konsumenckim na przykładzie wybranych umów (Lexis Nexis 2009) 69-82.

${ }^{18}$ Machnikowski (n 12) 152. 


\section{MERGER CLAUSES AND INTERPRETATION OF A CONTRACT}

As far as the influence of merger clauses on interpretation is concerned, we should begin with some insight into Polish legal provisions governing contract interpretation. The concept of interpretation of contracts ${ }^{19}$ under Polish civil law is spelled out in Art. 65 of the Polish Civil Code. It contains two methods of interpretation: subjective and objective, which together comprise the so-called combined theory of interpretation ${ }^{20}$. As such, the provision under discussion is in harmony with the majority European Union Member States' legal regimes, which also combine the subjective and objective methods ${ }^{21}$.

In Polish law, as in the majority of legal orders, priority is given to the subjective method ${ }^{22}$. This means that the interpreter (the court or arbitrator) should start the process of interpretation by trying to ascertain the parties' common intention at the time the contract was concluded. A contract is supposed to reflect the parties' will. Therefore, if there is a conflict between the parties' common intention and the literal meaning of contractual provisions, the former should prevail. It is worth emphasizing that subjective interpretation is not limited to instances in which the parties agree as to the meaning of the contract ${ }^{23}$. Hence, the subjective method can be applied even if the parties are in dispute as to the meaning of the contract, claiming to have understood its terms differently. When they do so, the question arises of how the parties' common intention is to be determined. According to the generally accepted understanding of legal scholars, the common intention should be ascertained by looking at how the parties acted during the negotiations and at (after) the moment of the contract's conclusion. Examples of factors relevant to interpretation often cited in legal literature include statements made by the parties to each other and to others in which the parties reveal how they understood the contract provisions, as well as the manner in which the contract is performed ${ }^{24}$.

If the interpreter fails to establish the common intention of the parties (especially when there is no evidence available), the objective method of interpretation should be employed ${ }^{25}$. At this stage of interpretation the contract should be given the meaning that a reasonable

${ }^{19}$ It needs to be underlined, however, that the range of appliacion of the provision in question is wider; it regards not only contracts, but all the juridical acts (also unilateral).

${ }^{20}$ Zbigniew Radwański, Wykładnia oświadczeń woli składanych indywidualnym adresatom (Zakład Narodowy im. Ossolińskich 1992) 60; Andrzej Janiak in Andrzej Kidyba (ed), 'Kodeks Cywilny. Komentarz. Tom I. Część Ogólna', (Wolters Kluwer business 2009) 388; Jarosław Grykiel in Jarosław Grykiel, Marcin Lemkowski (eds) Czynności prawne. Art. 56-81 KC (C.H. Beck 2010) 176; Machnikowski (n 13) 161.

${ }^{21}$ See Ole Lando and Hugh Beale (eds), The Principles Of European Contract Law, Parts I and II (Kluwer Law International 2000) 288 - 291; Christian von Bar and Eric Clive (eds), Principles, Definitions and Model Rules of European Private Law: Draft Common Frame of Reference (DCFR). Full edition (Sellier, European Law Publishers 2009) 553-560; Ewa Rott-Pietrzyk, 'Interpretacja oświadczeń woli (Uwagi na tle rozwiązań księgi I Kodeksu cywilnego)’ (2010) 4 Transformacje Prawa Prywatnego 47.

${ }^{22}$ Rott-Pietrzyk (n 21) 47-48.

${ }^{23}$ Radwański (n 20) 81; Machnikowski (n 13) 163; Grykiel (n 20) 179.

${ }^{24}$ See Radwański (n 20) 81.

${ }^{25}$ Grykiel (n 20) 179; Machnikowski (n 13) 162. 
person would attribute to it when placed in circumstances equivalent to those that the parties to a contract were in when the contract was formed ${ }^{26}$. This means that while determining the meaning of the contract, all circumstances surrounding its conclusion and all background information (the entire context) available to and perceivable by a reasonable person should be taken into account. The result of objective interpretation is primarily a strict reading, i.e. the normal (plain) meaning of the expressions used in the contract. The understanding ascribed to the contract within the framework of objective interpretation might nevertheless deviate from the regular meaning of the words used in it. This would be the case if, for example, one party intended an expression used in the contract to have a particular meaning and the other party could be expected to have been aware of that intention at the time of the contract's conclusion ${ }^{27}$. The contract is to be interpreted in this way when there is evidence available indicating how the first party understood the contract and how the second party should have understood it; this is usually extrinsic evidence.

It is the almost unanimous opinion of Polish civil law scholars that the rules on interpretation spelled out in Art. 65 are mandatory and cannot be derogated by the parties. This leads some of them to the conclusion that merger clauses are void as they aim to modify mandatory rules ${ }^{28}$. They claim that, consequently, merger clauses cannot influence the process of interpretation. Their presence in a contract does not render the contract document the sole object of interpretation. The contract may still be imputed a meaning different from what is stated in the document, for despite the insertion of the merger clauses, the interpreter is entitled to resort to any available external evidence justifying a particular meaning of the contract that may not be consistent with the document ${ }^{29}$.

That the provisions of the law concerning interpretation are not to be overruled by a contract is beyond doubt. However, this does not exclude merger clauses' bearing on the process of interpretation. Merger clauses, although ineffective as prescriptive provisions, may still play an important role as non-normative ones. In other words, merger clauses can be deemed an indicator of the parties' intention to limit the scope of their obligations and rights to what can be read in the document (without consulting external evidence $)^{30}$. However, it should be stressed that merger clauses interpreted in this way never exclude the possibility to demonstrate otherwise. The parties are free to state that a merger clause does not reflect their real will. This can be proven by delivering additional documentary evidence that supports the parties' allegations that one or more of them understood the contract in the light of statements made orally but not embodied in the contract document. Thus, the opinion of some scholars as presented above can be summarised in the following conclusion: merger clauses are evidence of the parties' intention to understand the contract as composed within the

${ }^{26}$ Janiak (n 20) 389; Grykiel (n 20) 177.

${ }^{27}$ Radwański (n 20) 95.

${ }^{28}$ Łolik (n 9) 55; Romanowski (n 7) 10.

29 Łolik (n 9) 56; Romanowski (n 7) 9-10; See also M. Łolik Wspótczesne prawo kontraktów - wybrane zagadnienia (C.H. Becek 2014) 66-70.

${ }^{30}$ See Krekora-Zając (n 9) 78; Szlęzak (n 9) 31-33; Marlena Pecyna Merger clause jako zastrzeżenie wyłączności dokumentu, klauzula integralności umowy, reguła wykładni umowy (Wolters Kluwer 2013) 243. 
four corners of the document, and as such they should be taken into account in the absence of evidence to the contrary. In my opinion, the consequences of using merger clauses in contracts are more far-reaching than that ${ }^{31}$. Even where there is no common intention to understand a contract only in line with the contract document, a merger clause should preclude the interpreter from ascribing to it a meaning consistent with external circumstances. I share the opinion that merger clauses inserted into a contract should rather be viewed as a means of interpretation (circumstances relevant for interpretation), and not as regulating the process of interpretation. However, I am convinced that merger clauses as such are not only to be used during the process of subjective interpretation, but that they also have a bearing on what is called objective interpretation. A reasonable person confronted with a clause labelling the contract document an 'entire contract and understanding between the parties' should seek such a meaning of the contract as can be inferred from its mere reading rather than a meaning determined with reference to external circumstances 32 . The presence of a merger clause leaves room for external interpretation only where the expressions of the contract are completely incomprehensible without resorting to external evidence.

\section{MERGER CLAUSES VERSUS PRIOR AGREEMENTS}

As mentioned above, merger clauses purport to preclude binding force of statements made by the parties and their undertakings prior to the signing of the contract document. The parties expect that when a contract contains a merger clause, all the agreements concluded before the contract was signed, be they oral or implied (made per facta concludentia), may not be held as a part of it. In the Polish legal literature this effect of merger clauses has rarely been the subject of consideration. Nonetheless, it is argued that merger clauses cannot have the effect in question. The purported reason is that the Polish Civil Code does not provide a rule analogous to Art. 2:105 PECL or Art. II - 4:104 DCFR ${ }^{33}$. As a consequence, merger clauses are said to raise a presumption that the contract document is complete, which may, however, be rebutted by any kind of proof ${ }^{34}$. This argumentation seems fallacious. In my opinion, in a vast majority of cases agreements made before a written contract was signed are in fact deprived of their binding effect upon the parties if the written contract they have signed contains a merger clause. As a starting point for explaining this view some general remarks must be made. Under the fundamental principle of freedom of contract, the parties are free to modify their contract at any time and in any way they see fit. Apart from the requirements that must be fulfilled by any agreement to be binding, there are no special formalities prescribed for an agreement to modify a contract. In particular, it is not necessary for it to

\footnotetext{
${ }^{31}$ Strugała (n 8) 265-266.

32 See Przemysław Gorzko, Mirosław Gumularz, 'Dopuszczalność i konsekwencje zastrzeżenia klauzuli merger’ 2013 (1) Kwartalnik Prawa Prywatnego 109.

${ }^{33}$ Łolik (n 9) 58.

${ }^{34}$ Łolik (n 9) 58; Romanowski (n 7) 11; See also Pecyna (n 30) 130-135.
} 
be given a particular title or to be structured in any particular way35. Whether the parties intend to modify a contract subsequently entered into is a question of interpretation. In any case, to establish such intention it is sufficient that the agreement determines which contract is about to be modified and what the content of the modification is 36 . In other words, for an agreement to be held to modify a contract previously concluded, it must render the contract materially different from the one initially concluded. The difference could consist in either establishing some additional rights and obligations which were not expressed in the original contract, or in extinguishing rights the parties originally enjoyed under the contract. The latter effect can be achieved by using a merger clause ${ }^{37}$.

Summarising this part of the paper, I find merger clauses far more significant than they are commonly thought of. They should be perceived as an issue of substantive law, as they modify the legal relationship and extinguish rights and obligations resulting from agreements made (including implicitly) before the contract document was signed. Conversely, they do not influence the process of applying evidentiary law. They do not raise any kind of presumption which could be rebutted. Where parties have used a merger clause, there is no point proving any precedent agreements because, extinguished by virtue of the merger clause, they are no longer binding upon the parties. This conclusion, however, is conditioned upon two following assumptions. First, it is indispensable that the agreements made by the parties before the signing of the contract document containing the merger clause constitutes a valid contract. From this it follows, inter alia, that the intention to create a legal relationship must exist38. Where there is no such intention, the contract is deemed to be concluded at the moment of signing the written document and, if so, the issue in question does not arise at all. The preliminary agreements are not to be considered part of the contract. They only constitute the context of the contract which may be used within the framework of its interpretation. The second assumption is that the precedent agreement and the contract embodied in the written document containing the merger clause address the same subject matter. Both of the contracts must concern the same legal relationship in the sense that the first (i.e. orally made) gives rise to it, and the second (embodied in the document in question) modifies it. If the contracts do not have the same subject matter, there is a serious doubt whether a merger clause put into the second contract may render the first one non-binding upon the parties. It would seem to depend on the language used in a given merger clause.

\footnotetext{
35 See Machnikowski (n 12) 148.

${ }^{36}$ Piotr Machnikowski, 'Treść umowy' in Ewa Łętowska (ed), System prawa prywatnego. Tom 5. Prawo zobowiazań-część ogólna (C.H. Beck 2006) 461; Machnikowski (n 12) 148.

${ }^{37}$ Strugała (n 8) $251-162$.

${ }^{38}$ Followed by the offer and acceptance or presumed pursuant to art 72 (1) of the Polish Civil Code.
} 


\section{MERGER CLAUSES VERSUS PRE-CONTRACTUAL STATEMENTS}

Apart from their influence on the process of interpretation and determination of the terms of a contract, merger clauses are purported to have other legal effects which deserve attention. They are considered to mitigate the binding effect of pre-contractual statements ${ }^{39}$. It must be stressed that in Polish legal scholarship the term 'pre-contractual statements' is very ambiguous, and may be misleading. The problem of the relation between pre-contractual statements and merger clauses arises when these statements are understood in the meaning of Art II. - 9:102 DCFR. Pursuant to the provision in comment, certain statements made before a contract is concluded may become part of the contract even though not expressed as terms of the contract, if they set reasonable expectations of the party to whom the statements are made ${ }^{40}$. Notwithstanding the prospect of the binding nature that such a general provision may have in the future (see Art. 69 of the CESL), it is important to note that its ratio legis is similar to that underlying Art. 2(2) of the Consumer Sales Directive of May 1999 (Directive 99/44/EC of the European Parliament and of the Council) ${ }^{41}$. Thus, the legal concept of certain pre-contractual statements becoming part of a contract is known in Poland as a result of implementation of EU Directives. Good examples of this concept are Art. 12 (2) of the Act of 27 July 2002 on specific terms and conditions of consumer sale and amendments to the Civil Code, and Art. 4(2) \& 4(3) of the Act of 29 August 1997 on tourist services. In the legal literature many ways of explaining the meaning of these provisions have been presented, but none of the them seem to be shared without reservation. As far as I am concerned, the most plausible explanation appears to be the one according to which statements made before the conclusion of a contract become part of the contract ${ }^{42}$. However, the binding effect of pre-contractual statements is excluded where the decision of the parties addressed by the statement to conclude the contract was not influenced by the statement or, generally speaking, the statement has not set reasonable expectations in the given circumstances ${ }^{43}$.

Given the protective purpose of the provisions in question, it is beyond any doubt that they are mandatory rules ${ }^{44}$. The parties may not derogate from them. From what has been established above it follows, however, that this conclusion does not mean that merger clauses never exert influence on the binding force of pre-contractual statements. They may still count as evidence of what kinds of expectations could be deemed

\footnotetext{
${ }^{39}$ Zoll (n 11) 62.

${ }^{40}$ See for more details von Bar, Clive (21) 583.

${ }^{41}$ von Bar, Clive (21) 584. Beck 2010) 17-18; Włodarska-Dziurzyńska (n 17) 116.

${ }^{43}$ See Włodarska-Dziurzyńska (17) 17; Mikłaszewicz (42) 307.

${ }^{44}$ See art 69 (4) of the CESL.
}

42 Przemysław Mikłaszewicz, Obowiązi informacyjne $w$ umowach $z$ udziałem konsumentów na tle prawa Unii Europejskiej (Wolters Kluwer business 2008) 306; Piotr Machnikowski, Prawne instrumenty ochrony zaufania przy zawieraniu umowy (Wydawnictwo Uniwersytetu Wrocławskiego 2010) 128; Fryderyk Zoll, 'Wykonywanie i skutki niewykonania lub nienależytego wykonania zobowiązań' in Adam Olejniczak (ed), System prawa prywatnego. Prawo zobowiazań - część ogólna. Suplement (C.H. 
reasonable ${ }^{45}$

\section{MERGER CLAUSES VERSUS FILLING GAPS}

The next question to be asked is whether merger clauses may affect the application of Art. 56 of the Polish Civil Code ${ }^{46}$. Pursuant to this provision, a contract has not only the juridical effects agreed on by the parties, but also those which result from the law, the principles of community life ${ }^{47}$ and custom. This provision referes to the concept of complete and incomplete contracts. Whereas the former fully specifies the rights and duties of the parties to the contract for all possible future circumstances, the latter contains gaps. Since real contracts are incomplete, the purpose of the sources of the terms of contract set out in Art. 56 is to fill in the gaps. The legal consequences deriving from law, the principles of community life and custom come into play every time there is a gap in a contract, irrespective of whether the parties are aware of this effect ${ }^{48}$. It is a commonly-held opinion among Polish scholars that these sources have a certain order which is reflected in the language of Art. 56: rules of law are first to complement the contract, but when there is no applicable rule of law, the principles of community life and/or custom provide a solution ${ }^{49}$. The implication of the given order would seem to be that, within the scope of application of the rules of law, principles of community life and custom that may exist are irrelevant ${ }^{50}$. In other words, if the same matters are covered by both rules of law and existing principles of community life or custom, only the former source can complement the provisions of the contract. This calls for the conclusion that the parties cannot exclude the application of the rules of law, rendering the principles of community life or custom applicable instead. They may, of course, expressly agree on legal consequences that are analogous to those stemming from custom or the principles of community life, but where the parties exclude the application of rules of law and do not provide any legal consequences themselves, the contract remains silent (has gaps).

As to statutory provisions (law), it is necessary to draw a line between mandatory (semi-mandatory) rules and default rules. Insofar as the first type of rules is concerned, it is clear that the parties to a contract cannot exclude their application by any kind of contractual clauses. This is true not only for the merger clauses analysed in this paper, but also for clauses which

45 Strugała (n 8) 269 - 273; Gorzko, Gumularz (n 32) 299; Pecyna (n 30) 42 -426.

${ }^{46}$ Again, like in the case of the art 65, the range of application of the provision is wider, as it concerns not only contracts, but also juridical acts.

${ }^{47}$ The concept of the principles of community life (morals) might be seen as the counterpart of the good faith and fair dealing concept. See Piotr Machnikowski, Justyna Balcarczyk, Monika Drela, Contract law in Poland (Wolters Kluwer 2011) 40-41.

${ }^{48}$ Marek Safjan, 'Refleksje o roli zwyczaju' in Nowińska (ed) Prawo Prywatne czasu przemian. Księga pamiatkowa dedykowana Profesorowi Stanisławowi Soltysińskiemu (2005) 102; Machnikowski (n 13) 133; Janiak (n 20) 301.

49 E Łętowska, 'Wprowadzenie do części ogólnej zobowiązań' in Ewa Łętowska (ed), System prawa prywatnego. Tom 5. Prawo zobowiazań - część ogólna (C.H. Beck 2006) 22-23; Machnikowski (n 13) 133.

50 See Zbigniew Radwański, Maciej Zieliński, 'Normy i przepisy prawa cywilnego' in Marek Safjan (ed) System prawa prywatnego. Tom 1. Prawo cywilne - czesść ogólna (C.H. Beck 2007) 338; See also Strugała (n 8) 267. 
purport to exclude statutory provisions more deliberately. The same answer should be given to the question of whether a merger clause may preclude the court from filling contractual gaps by applying custom or principles of community life. While to the best of my knowledge there is no extensive Polish legal literature examining this problem, it seems self-evident to me that the parties to a contract may exclude the application of neither custom nor the principles of community life ${ }^{51}$.

When it comes to default rules, it is clear from their very nature that parties are free to exclude their application as well as derogate from or amend their effects. In the Polish civil law, it is deemed possible that the parties exclude the default rule by providing a different rule or by stating that it is not to be applied, without providing any contractual rule instead. Bearing this in mind, prima facie a merger clause seems to be a statement aimed at excluding all default rules applicable to the contract it is found in. Yet when considering it in more detail, a stricter interpretation of merger clauses seems to be preferable ${ }^{52}$. To clarify this standpoint, a closer look must be taken at the complementary role of default rules. As was said above, contracts (declarations of will) express norms prescribing or forbidding a course of conduct. A complete norm contains certain fixed elements, such as the conditions of its application (i.e. the circumstances under which a norm is to be applied), the subject (i.e. the person or entity to whom a norm is addressed) and the object of a norm (i.e. the actions that a norm prescribes). When analysing default rules in the Polish civil law, one can notice that some of them complete a norm when it is only partially expressed in a contract (when it does not express all the elements of the norm). This is true in the case of Art. 455 of the Polish Civil Code, according to which if the time at which an obligation is to be performed has not been agreed on and cannot be determined from the nature of the obligation, the obligation shall be performed without undue delay upon the debtor being called on to do so. Without this provision, a contractual norm imposing an obligation would be incomplete, because it would be impossible to say when the obligation should be performed. As was highlighted above, the gap could not be filled in by the principles of community life, nor by custom. If a merger clause could exclude the application of a respective default rule, it would result in the invalidity of the contract (as a whole) or in its partial invalidity because of insufficiency of the contract. Thus, it turns out that the broad interpretation of merger clauses as excluding the application of any kind of default rules can not be accepted. The benigna interpretatio (or favor contractus) principle apparently speaks against this broad interpretation of merger clauses. According to this principle, commonly accepted in Polish legal scholarship and jurisprudence, when interpreting contracts (juridical acts), an interpretation allowing the contract to remain effective is to be preferred to other possible interpretations which would render it void.

In some other cases, however, default rules have a somewhat different function: they either impose additional obligations not expressed by the parties or modify the obligations expressed in the contract (modify

\footnotetext{
${ }^{51}$ See Pecyna (n 30) 467; M. Łolik (n 29) 68; Strugała (n 8) 267 - 269.

${ }^{52}$ See Strugała (n 8) 269.
} 
norms expressed in it), but do not complete norms that would be otherwise incomplete. For example, according to Art. 370 of the Polish Civil Code, the liability of two or more debtors to perform an obligation concerning their common property is solidary unless agreed otherwise. When read in conjunction with Art. 369 (an obligation is solidary if this results from statute or has been provided for), Art. 370 appears to modify the obligation of the parties so that it is solidary. If the application of Art. 370 is excluded, it does not render a contract concerning the common property of two debtors void. It would only imply that their obligation is not solidary (it is divided). It is plausible that a merger clause put into a contract may be interpreted as excluding the application of default rules having the aforementioned effect of modifying obligations expressed in the contract.

\section{CONCLUDING REMARKS}

As we have seen, merger clauses inserted into a contract document may effectively limit the sources of the parties' rights and obligations to the content of the contract document. This is mostly because the parties are empowered to determine their own legal situation on the basis of freedom of contract (see sections III and V above). The findings given above show that merger clauses may also influence the process of contract interpretation even though the rules of interpretation cannot be overruled by contract. The same is true for legislative provisions which automatically render some precontractual statements part of the contract. These provisions, although said to be mandatory, may also be excluded by merger clauses. In both cases this is because merger clauses can be viewed as evidence of relevant facts. As far as subjective interpretation is concerned, they may be deemed evidence of the common intention of the parties to understand the contract within the four corners of the document. Whereas in the case of objective interpretation or of pre-contractual statements, merger clauses make it easier to prove that there are no reasonable expectations as to extrinsic circumstances (statements or undertakings) becoming part of the contract or serving as means of its interpretation. The idea of judging the psychological state of people (their intentions) by the way they act (by what they do or say) is widely recognised in Polish legal theory. It is clear that the use of merger clauses as evidence of parties' intentions or expectations is convincing as long as they are provided by them or at least familiar to them. In the Polish law, however, there is no need to provide proof of such, since certain presumptions provided in the Code of Civil Procedure (Art. 244 and 245) make this proof redundant. In short, what follows from these presumptions is that persons who sign a document are aware of the whole content of the document, be it declarations of will or other statements and utterances.

At this point an explanation may be provided for why the effects of merger clauses inserted into standard terms of contract require separate consideration. An essential aspect of standard terms of contract is that they are formulated in advance for an indefinite number of future transactions, and as such they are not individually negotiated by the parties. Notwithstanding this feature, they may appear in different forms, being a part of the contract document or a separate document. Usually they are separate documents which are not signed by the parties to a contract. In this 
case, they are not covered by the presumptions set out in Art. 244 and 245 of the Code of Civil Procedure. From this it follows that in most cases their evidentiary function is negligible, as in order to consider them to be convincing evidence, it would be necessary to prove that the parties were aware of their presence in the standard terms of contract. To conclude this point, it is very important to emphasise that the mere observance of the conditions of the incorporation of standard terms of contract does not necessarily mean that the clauses contained in the standard terms may constitute plausible evidence. The binding effect of contractual clauses as normative ones and the evidentiary importance of contractual clauses are two different things. In the Polish civil law it is possible, at least in some cases, for standard terms to be incorporated into a contract (become a part of it) only if they are made easily accessible to the other party ${ }^{53}$. It is quite obvious that no conclusion may be drawn from the fact that the standard terms were made accessible as to whether they were read in detail. In my view, it is also doubtful whether merger clauses put into standard terms of contract may influence the parties' prior agreements, i.e. have the effect described in section III of this paper. As explained in that section, the effect in question can be achieved because the merger clause is considered to be a subsequent contract to modify the prior contract. However, to conclude this or any other contract, the agreement of the parties is necessary. Again, the mere incorporation of standard terms does not amount in any case to the agreement of the parties. Standard terms can be incorporated into a contract to complement it when it is validly concluded between the parties, and cannot replace the agreement of the parties ${ }^{54}$. Thus, as a result of merger clauses constituting an independent contract (modification contract), they cannot bring about the effect described in section III when not agreed on by the parties.

As said above, in conclusion a juxtaposition should be made between the effects of merger clauses under Polish and European private law. The effects of merger clauses under Polish law seem to most resemble those set out in the DCFR, as they ascribe lesser importance to clauses contained in the standard terms of contract than to those inserted into the contract document (see Art. II.-4:104 (2) DCFR). Unlike under Polish law, none of the European private law model rules preclude the parties' prior statements from being used to interpret a contract containing a merger clause. Notwithstanding this difference, merger clauses' effects under Polish and European private law do not differ as significantly as is sometimes said in the literature. Whether this should be assessed positively must be left for further studies on merger clauses' effects under European private law and the consideration of the reader.

${ }^{53}$ See Krzysztof Zagrobelny in Edward Gniewek (ed), Kodeks cywilny. Komentarz (C.H. Beck 2006) 583-588.

${ }^{54}$ Fryderyk Zoll, 'Natura prawna wzorców umownych' (1998) Państwo i Prawo 5, 57; Małgorzata Bednarek, Wzorce umów w prawie polskim (C.H. Beck 2005) 170; Maciej Skory, Klauzule abuzywne w polskim prawie ochrony konsumenta (Zakamycze 2005) 144; Radwański (n 12) 93. 